\title{
Tensile Behavior of PLA and PLA Composite Materials Under Different Printing Parameters
}

\author{
TIBERIU DOBRESCU ${ }^{1 *}$, NICOLETA-ELISABETA PASCU ${ }^{2}$, GABRIEL JIGA $^{3}$, IONEL SIMION ${ }^{2}$, VICTOR ADIR ${ }^{2}$, GEORGE ENCIU ${ }^{1}$, \\ DANIELA IOANA TUDOSE 3 \\ ${ }^{1}$ University Politehnica of Bucharest, Machine and Production Systems Department, 313 Splaiul Independentei, 060042, Bucharest, Romania \\ ${ }^{2}$ University Poltehnica of Bucharest, Engineering Graphics and Industrial Design Department, 313 Splaiul Independentei, 060042, Bucharest, \\ Romania \\ ${ }^{3}$ University Politehnica of Bucharest, Strength of Materials Department, 313 Splaiul Independentei, 060042, Bucharest, Romania
}

Polylactic acid (PLA) is one of the most extensively used biodegradable aliphatic polyester produced from renewable resources, such as corn starch. Due to its qualities, PLA is a leading biomaterial for numerous applications in medicine as well as in industry, replacing conventional petrochemical - based polymers. The purpose of this paper is to highlight the mechanical properties, such as tensile stress, of pure PLA specimens in comparison with PLA based-composites, with three different added materials in PLA mass: Copper, Aluminum and Graphene, as well as the influence of filament angle deposition on these properties. In order to check if the the filling density of the specimen influences the ultimate tensile stress (UTS), three different filling percentages $(60 \%, 80 \%$ and $100 \%)$ have been chosen in the experimental tests. In this context, the mechanical characteristics of four different filament types based on PLA material, starting from pure PLA to PLA with Aluminum, Copper or Graphene filler are compared. Understanding and controlling these parameters is essential for the successful use of PLA and PLA-based composites in different areas such as medical applications, sport equipments and light industry.These tests have been performed due to the fact there is a lack of information concerning the mechanical properties. In the scientific literature, such information is only available for expensive printing systems; for open source printers (as those used in these tests), the information is poor and for some new materials, even inexistant. According to the technical specifications, for an expensive printer the cost may exceed 3000 Euros, with a minimum layer resolution of $100 \mu \mathrm{m}$, this type of printer can reliably reproduce many $3 D$ objects accurately, in quiter conditions.

Keywords: composite filament, l 3D printing, fused deposition modeling

PLA polymers are synthesized and acquired from renewable agricultural resources, such as sugar cane and corn, by the polymerization of lactide, the cyclic di-ester of lactic acid. PLA is a polyester composed of lactic acid building blocks [1]. PLA is classified as a "thermoplastic" polyester. A major useful attribute about thermoplastics is that they can be heated to their melting point, cooled, and reheated again without significant degradation. People is becoming aware of the risks of environmental degradation, the current trends in the use of these biodegradable materials reinforcing this assertion. Nowadays, a widespread use of PLA for consumer goods is an optimistic alternative solution necessary to reduce the problems associated with the existence of solid waste from petroleum-based plastics. Worldwide there is a great interest in the so-called "green polymers" due to the fact it provides a clear answer to the economically sustainable development contributing to the preservation of fossilraw materials, reducing the volume of garbage through bio-degradability in the natural cycle that leads to the protection climate [2]. The lactic acid is the most widespread carboxylic acid in nature [3].

Initially, lactic acid was a petrochemical derivative [3]. PLA has performance properties comparable to those of traditional thermoplastic materials (i.e. PMMA, ABS etc.) [4]. PLA polymers range from "amorphous glassy polymers" with a transition temperature of about $50-60\left[{ }^{\circ} \mathrm{C}\right]$, to semi crystalline products with melting points ranging from 80-130 $\left[{ }^{\circ} \mathrm{C}\right]$ [5]. This makes them fairly unsuitable for high temperature applications [6]. Commercial PLA classes are copolymers of poly L-lactic acid - PLLA and poly D, L-lactic acid PDLLA [7]. The ratio between L and D enantiomers affects the PLA properties, namely the melting temperature and degree of crystallinity. Introduction of stereo chemical defects into poly (L-lactide) reduces the melting point, the rate of crystallization, and the extent of crystallization of the resulting polymer but has little effect on glass transitiontemperature [8].

*email: tibidobrescu@yahoo.com 
PLA has good mechanical properties, thermal plasticity and biocompatibility, is easy to be manufactured. PLA has a high Young modulus and high strength and is not a tough material. PLA resistance can be enhanced by copolymerization [8]. One major disadvantage of PLA is its durability. Consequently, this material is to not being used in automotive industry.

In the production environment of 3D printing products, Polylactic Acid (PLA) is much more widely applicable than ABS, Nylon and various blends of polycarbonate. It is used for 3D printing material with FDM (Fused Deposition Modeling) technology. Since PLA-based materials has a glass transition temperature between $\left(60-70{ }^{\circ} \mathrm{C}\right)$ it is more suitable to be used in FDM.

The FDM principle is based on the following steps: the extrusion material (filament input) is brought into a semi-solid state and forced through a nozzle to form a filament with a narrower diameter than the diameter of the input filament that will rapidly solidify after the extrusion. The input filament will be liquefied in a liquefaction chamber placed before the nozzle. The temperature in the liquefaction chamber is set so that the filament changes its state. The diameter of the filament resulting from the extrusion will remain constant if the movement of the nozzle on the surface is set to a constant speed. Figure 1 shows the extrusion system and its components.

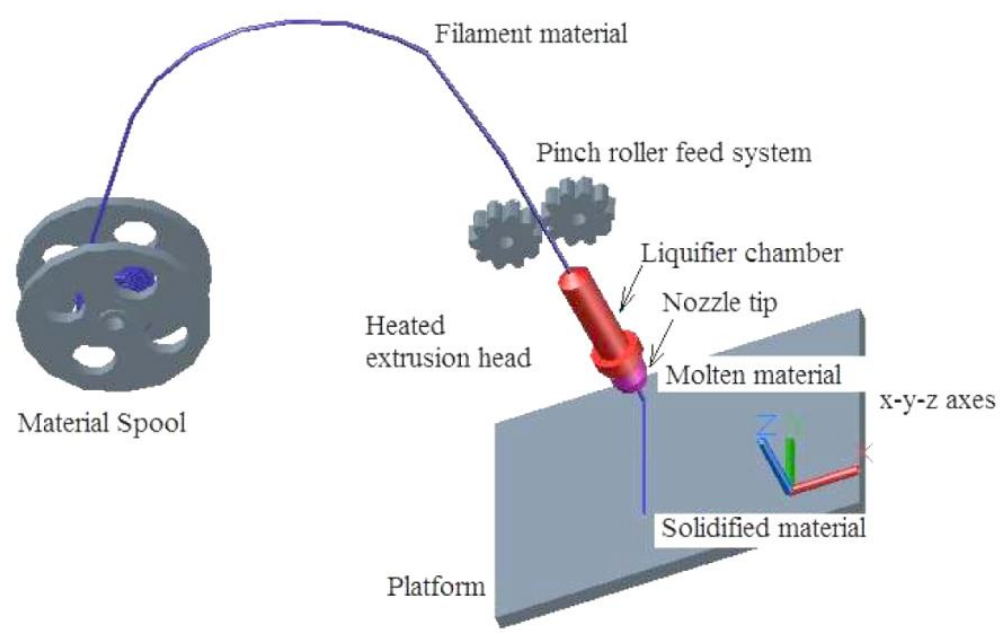

Fig. 1. FDM process

The testing of PLA new composite materials is required since they do not behave as expected by datasheets because of their anisotropy and largely unknowns' local material properties after extrusion.

Over the years, the properties of PLA materials have been the subject of extensive researches [9-11, 18-21]. The properties of PLA depend on its isomers, processing temperature and cooling time $[10,11]$. Besides these, the crystallinity rate is an important property of polymers (crystallinity indicates the rate of crystalline regions in the polymer that respects the amorphous content [12]). Crystallinity influences polymerproperties such as hardness, modulus of elasticity, tensile strength, stiffness and melting points.

One of the paper purpose is to highlight the influence of different printing parameters upon one mechanical characteristics such tensile stress, in order to manufacture different consumable components safe in exploitation for short periods of time. Very often, these components are useful in manufacturing, keeping the process up and running during the entire waiting time for the delivery of a new piece of equipment.

\section{Experimental part}

Materials and methods

Equipment and software applications

The specimens have been printed on a CREALITY 3D [13] printer equipment. The transfer of the specimen geometric model was performed using ".stl" files exported from AutoCAD version 2019 provided by Autodesk [14]. The software application for generating the G-code in the 3D modeling specimens used was Simplify 3D-version 3.1.0 [15]. Layer deposition is dependent on the extruded filament diameter which is applied in successive planes parallel to each other and perpendicular to the flow direction of the extruded material (Fig. 2). 


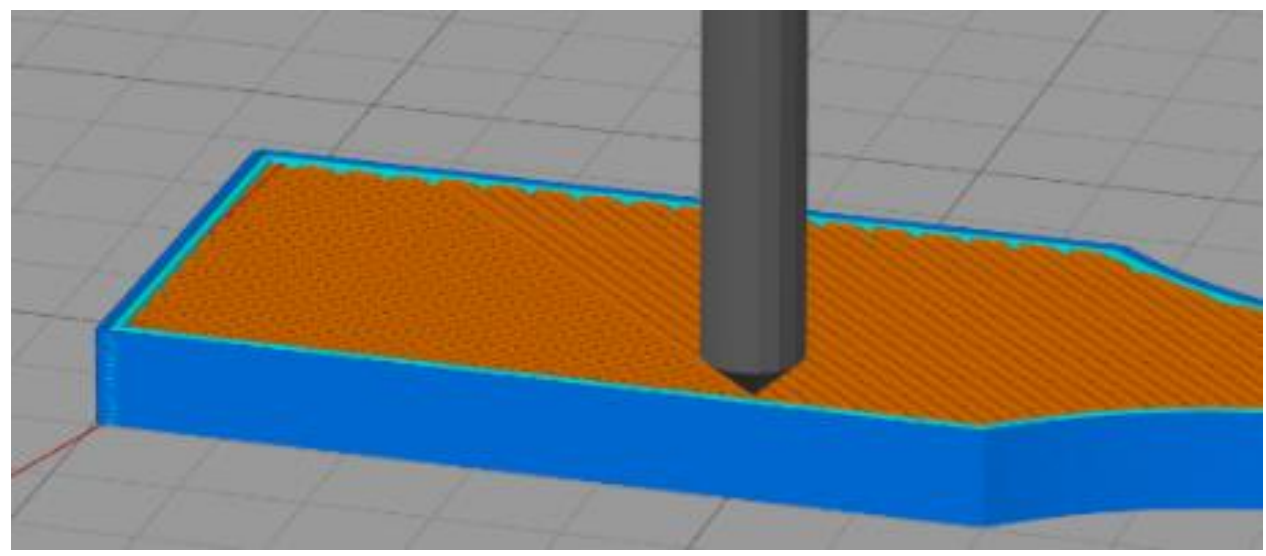

Fig. 2. Layer deposition

For the tests, 72 specimens were printed, with 18 samples of each material, taking into account the ASTM D638 standard and using a CREALITY 3D printer. All materials were purchased from different providers (Table1).

Table 1

3D PRINTING MATERIALS

\begin{tabular}{|c|c|}
\hline Material type & Providers \\
\hline PLA & Devil Design \\
\hline PLA - Copper & SainSmart \\
\hline PLA - Aluminum & SainSmart \\
\hline PLA - Graphene & FILOALFA \\
\hline
\end{tabular}

Concerning the printing methods three different filling densities of the specimen were used: $60 \%, 80 \%$ and $100 \%$. In order to evaluate the mechanical characteristics of the specimen as a function of stacking sequence of the layers deposition, two cross different layer orientations $\left( \pm 45^{\circ}\right.$ and $\left.\pm 60^{\circ}\right)$ have been taken into account. All specimens, regardless the material type, were printed at a same extrusion temperature. These temperatures and all tested materials are summarized in Table 2. Other printing parameters such as the layer height, the printing speed were adjusted identically for each material, using the supplier's recommendations to achieve print quality and uniformity for all specimens. The general printing conditions for all four materials require the PLA plastic material to be heated in the extruder at a temperature in the range $160-210\left[{ }^{\circ} \mathrm{C}\right]$ and the heating platform heated to a temperature in the range $0-60\left[{ }^{\circ} \mathrm{C}\right]$. The extrusion temperature and, implicitly, the extrusion die temperature were set at $205\left[{ }^{\circ} \mathrm{C}\right]$. The technicalcharacteristics of the printing filaments used in the tests are $1.75[\mathrm{~mm}]$ filament diameter, the filament diameter after extrusion being given by the diameter of the extrusion die 0.4 [mm]. The parameters of the printing process were not varied during the experiments: thus, the extrusion speed was set at $60[\mathrm{~mm} / \mathrm{s}]$, the way of how the specimens have been created being identical for each specimen.

Since this type of technology requires platform heating, this temperature was set to $55\left[{ }^{\circ} \mathrm{C}\right]$. The temperature of 55 $\left[{ }^{\circ} \mathrm{C}\right]$ was selected by the authors based on the experience gained in previous research studies and it falls in the range recommended by the filament manufacturers.

Table 2

3D PRINTING MATERIALS, PRINTING TEMPERATURE AND DENSITY OF THE FILAMENT

\begin{tabular}{|c|c|c|c|c|}
\hline Material type & $\begin{array}{c}\text { Printing } \\
\text { temperature } \\
{\left[{ }^{\circ} \mathrm{C}\right]}\end{array}$ & $\begin{array}{c}\text { Filament } \\
\text { density } \\
{\left[\mathrm{g} / \mathrm{cm}^{3}\right]}\end{array}$ & $\begin{array}{c}\text { Layer height } \\
{[\mathrm{mm}]}\end{array}$ & $\begin{array}{c}\text { Printing speed } \\
{[\mathrm{mm} / \mathrm{s}]}\end{array}$ \\
\hline PLA & 205 & 1.24 & 0.1 & 0.1 \\
\hline PLA60\% - Copper40\% & 205 & 3.90 & 0.1 & 60 \\
\hline $\begin{array}{c}\text { PLA60\% - Aluminum40\% } \\
\text { PLA - Graphene }\end{array}$ & 205 & 1.4 & 6.1 & 60 \\
\hline
\end{tabular}


The specimens used for tensile tests have been performed according to ASTM D638. This test method covers the determination of the tensile properties of unreinforced and reinforced plastics in the form of standard dumbbell-shaped test specimens when tested under defined conditions of pretreatment, temperature, humidity and testing machine speed. The geometrical characteristics of such a specimen are depicted in Figure 3.

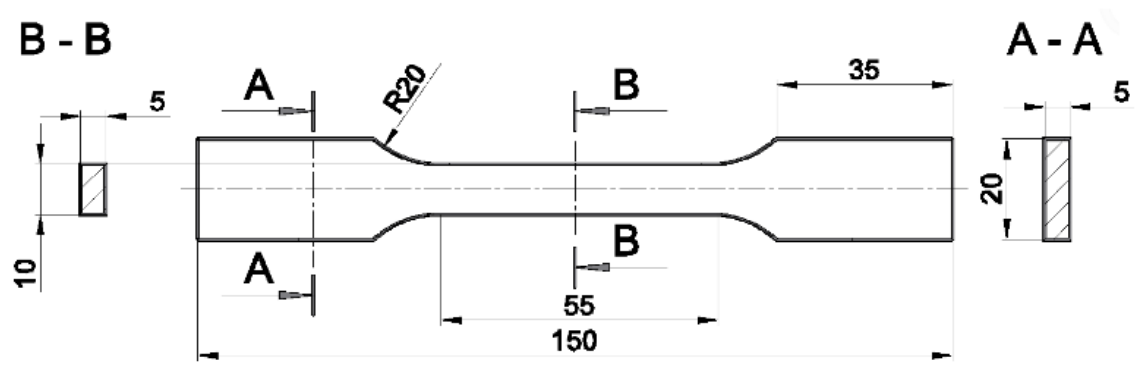

Fig. 3. Geometrical characteristics of specimen (units are given in [mm])

Thus, a set of bone-shaped specimens, with a length of 55 [mm] in the calibration area and a thickness of 5 [mm], was achieved. According to D618-00 Standard for conditioning plastics for testing, in case of PLA specimens was used Procedure A, where the specimens under $7 \mathrm{~mm}$ thickness were kept for $40 \mathrm{~h}$ at $23\left[{ }^{\circ} \mathrm{C}\right]$ and $50 \%$ relative humidity. Test specimens were tested in tension on a universal testing machine - INSTRON 8800. The test speed was 1 [mm/min]. This machine has a capacity of up to $100[\mathrm{kN}]$ and is equipped with hydraulic grips (from ambient temperature up to 1000 $\left.\left[{ }^{\mathrm{O}} \mathrm{C}\right]\right)$. This machine is also equipped with advanced devices: Digital Numeric Controller, Software Console and Dynacell Single Load INSTRON Cells [16].

\section{Materials}

In the experimental part, four types of filaments were used for the test specimens manufacturing: PLA (Polylactic acid), PLA with Copper powder, PLA with Aluminum powder and PLA with Graphene. Before printing, it is important for the material to be dry and the print media to be controlled (to have a constant temperature).

\section{PLA material without metallic powder coating}

PLA is available on the market in a wide range of variantsand depending on the different colors, they can be opaque or translucent. All these types of PLA heated to $160\left[{ }^{\circ} \mathrm{C}\right]$ adhere very well to the Kapton band or to the glass (through a glue). In tests the authors adopted the Kapton tape for bed addition. PLA thermoplastic polyester filament used for 3D printing using the FDM method is provided by Poland's "Devil Design" [22]. The characteristics of PLA filament (with a diameter of $1.75[\mathrm{~mm}])$ are shown in Table 3 and are specified by the manufacturer.

Table 3

PROCESSING INFORMATION OF PLA MATERIAL DELIVERED

\begin{tabular}{|c|c|c|}
\hline \multicolumn{3}{|c}{ BY DEVIL DESIGN } \\
$\begin{array}{c}\text { Nozzle } \\
\text { temperature }\end{array}$ & $\begin{array}{c}\text { Printing bed } \\
\text { temperature }\end{array}$ & Platform adhesion \\
\hline $200-235\left[{ }^{\circ} \mathrm{C}\right]$ & $50-60\left[{ }^{\circ} \mathrm{C}\right]$ & $\begin{array}{c}\text { Heated glass or } \\
\text { Kapton tape }\end{array}$ \\
\hline
\end{tabular}

\section{PLA material with metallic Copper powder coating}

PLA filaments with Copper powder insertion are made of 40\% Copper and 60\% PLA, being supplied by SainSmart. The characteristics of the filament with a diameter of $1.75 \mathrm{~mm}$ are shown in Table 4. 
Table 4

PLA WITH METALLIC COPPER POWDER

MATERIAL CHARACTERISTICS

\begin{tabular}{|c|c|c|}
\hline $\begin{array}{c}\text { Nozzle } \\
\text { temperature }\end{array}$ & $\begin{array}{c}\text { Printing bed } \\
\text { temperature }\end{array}$ & Platform adhesion \\
\hline $200-220\left[{ }^{\circ} \mathrm{C}\right]$ & $40-60\left[{ }^{\circ} \mathrm{C}\right]$ & $\begin{array}{c}\text { Heated glass or } \\
\text { Kapton tape }\end{array}$ \\
\hline
\end{tabular}

\section{PLA with Aluminum powder metal insertion}

PLA filaments with Aluminum powder insertion are made of $40 \%$ Aluminum and $60 \%$ PLA, being supplied by SainSmart. The characteristics of the Aluminum filament for 3D Printer with a diameter of $1.75 \mathrm{~mm}$ are identical to those in Table 4.

\section{PLA material with Graphene insertion}

PLA material with Graphene insertion supplied by FILOALFA and called GRAFYLON is a filament for 3D printing addicted with graphene, to provide excellent mechanical and aesthetic performance. GRAFYLON is suitable for the most popular printers on the market and is completely non-toxic and odorless till high temperatures. This material is a special filament with a very good mechanical strength and thermal conductivity coupled with a highly defined surface finish with priceless printing simplicity. Compared to a traditional PLA, GRAFYLON offers anelastic modulus: $+34 \%$, atensile strength: $+23 \%$, anelongation capacity: $+28 \%$ and ideal for printing finished objects [17]. The characteristics of the GRAFYLON filament for 3D Printer with a diameter of $1.75 \mathrm{~mm}$ are identical to those in Table 4 ..

\section{Results and discussions}

Table 5 summarizes the data generated during experimental printing. Thus, the specimens were rated from 1 to 18 for this type of material and ranked according to the deposition angle $\left( \pm 45^{\circ}, \pm 60^{\circ}\right)$ as well as function of the filling percentage of the specimens $(60 \%, 80 \%$ and $100 \%)$. Indeed, the scanning angle should vary from $0^{\circ}$ to $90^{\circ}$, but since at angles below $45^{\circ}$ the specimens failed at low values of tensile force (around $350 \mathrm{~N}$ ), the authors decided to study the tensile behavior at angles higher than $45^{\circ}$, considering that future experimental attempts to be performed from $45^{\circ}$ to $90^{\circ}$ from $5^{\circ}$ to $5^{\circ}$. Although the filament suppliers suggested printing components with a $100 \%$ density, the authors intended to highlight how the normal stress varies with decreasing of the filling density percentage.

Table 5

PLA - POLYLACTIC ACID

\begin{tabular}{|c|c|c|c|c|c|c|}
\hline Filling materials & \multicolumn{6}{|c|}{ Materials - PLA } \\
\hline Interior fill percentage - $\%$ & \multicolumn{2}{|c|}{$60 \%$} & \multicolumn{2}{|c|}{$80 \%$} & \multicolumn{2}{|c|}{$100 \%$} \\
\hline Infill angle & $\pm 45^{\circ}$ & $\pm 60^{\circ}$ & $\pm 45^{\circ}$ & $\pm 60^{\mathrm{O}}$ & $\pm 45^{\circ}$ & $\pm 60^{\circ}$ \\
\hline Number of samples tested & $1-3$ & $4-6$ & $7-9$ & $10-12$ & $13-15$ & $16-18$ \\
\hline $\begin{array}{l}\text { Build time provided by the softer } \\
\text { application [min] }\end{array}$ & 46 & 46 & 54 & 54 & 61 & 61 \\
\hline Real build time [min] & 54 & 57 & 65 & 67 & 74 & 78 \\
\hline Filament length [mm] & 3404.2 & 3402.2 & 4103.7 & 4103.3 & 4805.1 & 4804.2 \\
\hline Plastic weight $[\mathrm{g}]$ & 10.23 & 10.23 & 12.34 & 12.34 & 14.45 & 14.44 \\
\hline Filament density $\left[\mathrm{g} / \mathrm{cm}^{3}\right]$ & & & & & & \\
\hline
\end{tabular}

The tensile strength for the test group $1 \div 18$, PLA specimens, shows a rather significant trend from $17.41[\mathrm{MPa}]$ to 49.88 [MPa]. As it can be seen in Figure 4, 60\% and $100 \%$ warp specimens with thread deposition at $\pm 60^{\circ}$ are much more resistant in tension than $60 \%$ and $100 \%$ yarn specimens with thread deposition at $\pm 45^{\circ}$. Differences between fracture strength values for the same filling percentage for $60 \%$ and $80 \%$ samples but with a different deposition orientation of $\pm 45^{\circ}$ and $\pm 60^{\circ}$ are much lower compared to differences in fracture strength values for the same filling percentage of $100 \%$ specimen, but with a different loading orientation of $\pm 45^{\circ}$ and $\pm 60^{\circ}$ respectively. In Tables 6-11 are depicted the obtained data of tests performed on PLA samples. 
Table 6

PLA; INTERIOR FILL PERCENTAGE - 60\%; THREAD DEPOSITION AT $\pm 45^{\circ}$

\begin{tabular}{|c|c|c|c|}
\hline Specimen & $\begin{array}{c}\text { Force } \\
{[\mathrm{N}]}\end{array}$ & $\begin{array}{c}\text { Tensile stress } \\
{[\mathrm{MPa}]}\end{array}$ & $\begin{array}{c}\Delta \mathrm{L} \\
{[\mathrm{mm}]}\end{array}$ \\
\hline$\# 1$ & 750 & 14.96 & 2.5 \\
\hline$\# 2$ & 670 & 13.32 & 5.9 \\
\hline$\# 3$ & 1200 & 23.96 & 3.4 \\
\hline
\end{tabular}

Table 7

PLA; INTERIOR FILL PERCENTAGE - 60\%; THREAD DEPOSITION AT $\pm 60^{\circ}$

\begin{tabular}{|c|c|c|c|}
\hline Specimen & $\begin{array}{c}\text { Force } \\
{[\mathrm{N}]}\end{array}$ & $\begin{array}{c}\text { Tensile stress } \\
{[\mathrm{MPa}]}\end{array}$ & $\begin{array}{c}\Delta \mathrm{L} \\
{[\mathrm{mm}]}\end{array}$ \\
\hline$\# 4$ & 920 & 18.44 & 4.4 \\
\hline$\# 5$ & 970 & 19.34 & 4.8 \\
\hline$\# 6$ & 910 & 18.15 & 4.6 \\
\hline
\end{tabular}

Table 8

PLA; INTERIOR FILL PERCENTAGE - 80\%; THREAD DEPOSITION AT $\pm 45^{\circ}$

\begin{tabular}{|c|c|c|c|}
\hline Specimen & $\begin{array}{c}\text { Force } \\
{[\mathrm{N}]}\end{array}$ & $\begin{array}{c}\text { Tensile stress } \\
{[\mathrm{MPa}]}\end{array}$ & $\begin{array}{c}\Delta \mathrm{L} \\
{[\mathrm{mm}]}\end{array}$ \\
\hline$\# 7$ & 1560 & 31.21 & 2.38 \\
\hline$\# 8$ & 1570 & 31.36 & 2.31 \\
\hline$\# 9$ & 1610 & 32.15 & 2.4 \\
\hline
\end{tabular}

Table 9

PLA; INTERIOR FILL PERCENTAGE - 80\%; THREAD DEPOSITION AT $\pm 60^{\circ}$

\begin{tabular}{|c|c|c|c|}
\hline Specimen & $\begin{array}{c}\text { Force } \\
{[\mathrm{N}]}\end{array}$ & $\begin{array}{c}\text { Tensile stress } \\
{[\mathrm{MPa}]}\end{array}$ & $\begin{array}{c}\Delta \mathrm{L} \\
{[\mathrm{mm}]}\end{array}$ \\
\hline$\# 10$ & 1450 & 29.09 & 2.5 \\
\hline$\# 11$ & 1530 & 30.59 & 2.59 \\
\hline$\# 12$ & 1480 & 29.53 & 2.42 \\
\hline
\end{tabular}

Table 10

PLA; INTERIOR FILL PERCENTAGE - 100\%; THREAD DEPOSITION AT $\pm 45^{\circ}$

\begin{tabular}{|c|c|c|c|}
\hline Specimen & $\begin{array}{c}\text { Force } \\
{[\mathrm{N}]}\end{array}$ & $\begin{array}{c}\text { Tensile stress } \\
{[\mathrm{MPa}]}\end{array}$ & $\begin{array}{c}\Delta \mathrm{L} \\
{[\mathrm{mm}]}\end{array}$ \\
\hline$\# 13$ & 2320 & 46.44 & 2.7 \\
\hline$\# 14$ & 2170 & 43.47 & 2.9 \\
\hline$\# 15$ & 2240 & 44.83 & 3.6 \\
\hline
\end{tabular}


Table 11

PLA; INTERIOR FILL PERCENTAGE - 100\%; THREAD DEPOSITION AT $\pm 60^{\circ}$

\begin{tabular}{|c|c|c|c|}
\hline Specimen & $\begin{array}{c}\text { Force } \\
{[\mathrm{N}]}\end{array}$ & $\begin{array}{c}\text { Tensile stress } \\
{[\mathrm{MPa}]}\end{array}$ & $\begin{array}{c}\Delta \mathrm{L} \\
{[\mathrm{mm}]}\end{array}$ \\
\hline$\# 16$ & 2440 & 48.73 & 2.5 \\
\hline$\# 17$ & 248 & 49.53 & 2.21 \\
\hline$\# 18$ & 2570 & 51.39 & 2.1 \\
\hline & & & \\
\hline
\end{tabular}

PLA

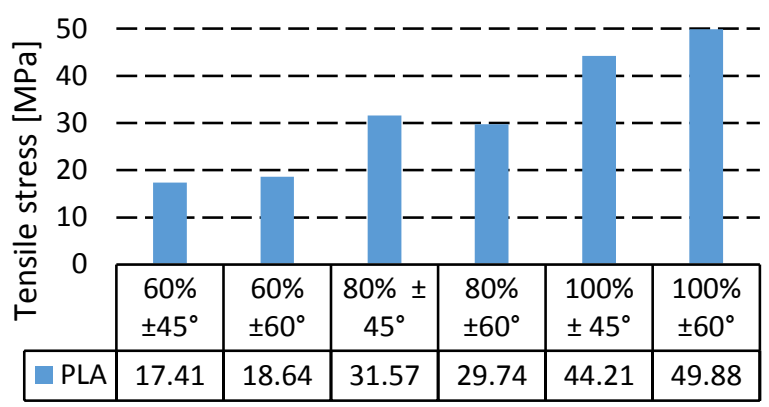

Interior fill percentage [\%] and Infill angle[ ${ }^{\circ}$ ]

Fig. 4. Values of fracture strength for PLA specimens

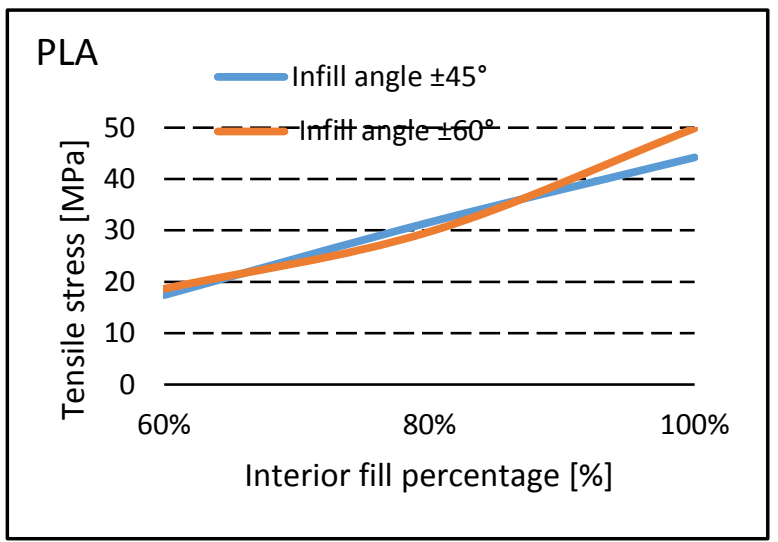

Fig. 5. Values of fracture strength for PLA specimens versus the filling percentage

In order to quantify the amount of variation of dispersion of the previous data set the standard deviation was calculated with the formula (Table 12):

$$
s=\sqrt{\frac{\sum_{i=1}^{N}\left(x_{i}-\bar{x}\right)^{2}}{N-1}}
$$


Table 12

STANDARD DISPERSION FOR PLA SPECIMENS

\begin{tabular}{|c|c|c|}
\hline Infill percentage/ Deposition angle & $\overline{\mathrm{x}}$ & $\mathrm{s}$ \\
\hline $60 \% / \pm 45^{\circ}$ & $13.74 \mathrm{MPa}$ & 0.912 \\
\hline $60 \% / \pm 60^{\circ}$ & $18.64 \mathrm{MPa}$ & 0.621 \\
\hline $80 \% / \pm 45^{\circ}$ & $31.57 \mathrm{MPa}$ & 0.505 \\
\hline $80 \% / \pm 60^{\circ}$ & $29.74 \mathrm{MPa}$ & 0.756 \\
\hline $100 \% / \pm 45^{\circ}$ & $44.91 \mathrm{MPa}$ & 1.486 \\
\hline $100 \% / \pm 60^{\circ}$ & $49.88 \mathrm{MPa}$ & 1.364 \\
\hline
\end{tabular}

For PLA specimens (Fig. 5) one can conclude that, in case of $\pm 45^{\circ}$ angle deposition, the graphic is rather a linear function, in comparison with those with a $\pm 60^{\circ}$ angle deposition, where the variation is rather exponential; this is due to the fact that for $\pm 45^{\circ}$ the specimen is totally „,balanced”, with respect to the XY machine coordinate system.

Moreover, in case of $60 \%$ angle deposition it is easily to be seen that as the percentage of filling increases, the graphic will present a steeper variation, concluding that it is advisable to have specimens with high fill percentage when high values of stresses are requested.

For low interior fill percentage, the infill angle does not affect the stress behavior. For values between approximately $65 \%$ and $85 \%$ filling percentage the specimens with an infill angle of $\pm 45^{\circ}$ have a better behavior regarding the tensile stress than the other ones. For specimens with an interior filling percentage over $85 \%$ it is suitable to make deposition with an infill angle of $60 \%$.

In Table 13 are synthesized data resulted during 3D printing process with PLA specimens with Copper powder insertion. The specimens were ranking from 19 to 36.

Table 13

PLA WITH COPPER POWDER

\begin{tabular}{|c|c|c|c|c|c|c|}
\hline Filling materials & \multicolumn{6}{|c|}{ Materials - Composite Metal: PLA + Copper } \\
\hline Interior fill percentage - $\%$ & \multicolumn{2}{|c|}{$60 \%$} & \multicolumn{2}{|c|}{$80 \%$} & \multicolumn{2}{|c|}{$100 \%$} \\
\hline Infill angle & $\pm 45^{\circ}$ & $\pm 60^{\circ}$ & $\pm 45^{\circ}$ & $\pm 60^{\circ}$ & $\pm 45^{\circ}$ & $\pm 60^{\circ}$ \\
\hline Number of samples tested & $19-21$ & $22-24$ & $25-27$ & $28-30$ & $31-33$ & $34-36$ \\
\hline $\begin{array}{l}\text { Build time provided by the softer } \\
\text { application [min] }\end{array}$ & 46 & 46 & 54 & 54 & 61 & 61 \\
\hline Real build time [min] & 55 & 57 & 65 & 67 & 75 & 77 \\
\hline Filament length [mm] & 3404.2 & 3402.2 & 4103.3 & 4103.7 & 4805.1 & 4804.2 \\
\hline Plastic weight $[\mathrm{g}]$ & 31.93 & 31.92 & 38.49 & 38.50 & 45.07 & 45.07 \\
\hline Filament density $\left[\mathrm{g} / \mathrm{cm}^{3}\right]$ & & & & & & \\
\hline
\end{tabular}

In Tables 14- 19 are depicted the obtained data of tests performed on PLA sampleswith Copper powder insertion.

Table 14

PLA WITH COPPER; INTERIOR FILL PERCENTAGE - 60\%; THREAD DEPOSITION AT $\pm 45^{\circ}$

\begin{tabular}{|c|c|c|c|}
\hline Specimen & $\begin{array}{c}\text { Force } \\
{[\mathrm{N}]}\end{array}$ & $\begin{array}{c}\text { Tensile stress } \\
{[\mathrm{MPa}]}\end{array}$ & $\begin{array}{c}\Delta \mathrm{L} \\
{[\mathrm{mm}]}\end{array}$ \\
\hline$\# 19$ & 1000 & 20.02 & 1.48 \\
\hline$\# 20$ & 1030 & 20.52 & 1.52 \\
\hline$\# 21$ & 990 & 19.84 & 1.53 \\
\hline
\end{tabular}

Table 15

PLA WITH COPPER; INTERIOR FILL PERCENTAGE - 60\%; THREAD DEPOSITION AT $\pm 60^{\circ}$

\begin{tabular}{|c|c|c|c|}
\hline Specimen & $\begin{array}{c}\text { Force } \\
{[\mathrm{N}]}\end{array}$ & $\begin{array}{c}\text { Tensile stress } \\
{[\mathrm{MPa}]}\end{array}$ & $\begin{array}{c}\Delta \mathrm{L} \\
{[\mathrm{mm}]}\end{array}$ \\
\hline$\# 22$ & 760 & 15.23 & 2.55 \\
\hline$\# 23$ & 770 & 15.45 & 2.7 \\
\hline$\# 24$ & 830 & 16.63 & 2.85 \\
\hline
\end{tabular}


Table 16

PLA WITH COPPER; INTERIOR FILL PERCENTAGE - 80\%; THREAD DEPOSITION AT $\pm 45^{\circ}$

\begin{tabular}{|c|c|c|c|}
\hline Specimen & $\begin{array}{c}\text { Force } \\
{[\mathrm{N}]}\end{array}$ & $\begin{array}{c}\text { Tensile stress } \\
{[\mathrm{MPa}]}\end{array}$ & $\begin{array}{c}\Delta \mathrm{L} \\
{[\mathrm{mm}]}\end{array}$ \\
\hline$\# 25$ & 1180 & 23.53 & 1.82 \\
\hline$\# 26$ & 1220 & 24.46 & 1.9 \\
\hline$\# 27$ & 1150 & 22.94 & 1.7 \\
\hline
\end{tabular}

Table 17

PLA WITH COPPER; INTERIOR FILL PERCENTAGE - 80\%; THREAD DEPOSITION AT $\pm 60^{\circ}$

\begin{tabular}{|c|c|c|c|}
\hline Specimen & $\begin{array}{c}\text { Force } \\
{[\mathrm{N}]}\end{array}$ & $\begin{array}{c}\text { Tensile stress } \\
{[\mathrm{MPa}]}\end{array}$ & $\begin{array}{c}\Delta \mathrm{L} \\
{[\mathrm{mm}]}\end{array}$ \\
\hline$\# 28$ & 930 & 18.66 & 1.85 \\
\hline$\# 29$ & 590 & 11.78 & 1.99 \\
\hline$\# 30$ & 970 & 19.39 & 2.07 \\
\hline
\end{tabular}

Table 18

PLA WITH COPPER; INTERIOR FILL PERCENTAGE - 100\%; THREAD DEPOSITION AT $\pm 45^{\circ}$

\begin{tabular}{|c|c|c|c|}
\hline Specimen & $\begin{array}{c}\text { Force } \\
{[\mathrm{N}]}\end{array}$ & $\begin{array}{c}\text { Tensile stress } \\
{[\mathrm{MPa}]}\end{array}$ & $\begin{array}{c}\Delta \mathrm{L} \\
{[\mathrm{mm}]}\end{array}$ \\
\hline$\# 31$ & 1620 & 32.31 & 1.69 \\
\hline$\# 32$ & 1540 & 30.74 & 1.7 \\
\hline$\# 33$ & 1540 & 30.84 & 1.83 \\
\hline
\end{tabular}

Table 19

PLA WITH COPPER; INTERIOR FILL PERCENTAGE - 100\%; THREAD DEPOSITION AT $\pm 60^{\circ}$

\begin{tabular}{|c|c|c|c|}
\hline Specimen & $\begin{array}{c}\text { Force } \\
{[\mathrm{N}]}\end{array}$ & $\begin{array}{c}\text { Tensile stress } \\
{[\mathrm{MPa}]}\end{array}$ & $\begin{array}{c}\Delta \mathrm{L} \\
{[\mathrm{mm}]}\end{array}$ \\
\hline$\# 34$ & 1500 & 30.02 & 1.8 \\
\hline$\# 35$ & 1520 & 30.46 & 2.01 \\
\hline$\# 36$ & 1500 & 29.93 & 1.82 \\
\hline
\end{tabular}

The tensile strength for the test specimens \# $19 \div 36$ performed on PLA specimens with Copper powder insertion (Fig. 6) shows a significant variation from $20.13[\mathrm{MPa}$ to 30.14 [MPa]. As it can be seen in Figure 6, the $60 \%, 80 \%$ and $100 \%$ fill patterns with thread deposition at $\pm 45^{\circ}$ are more resistant in tension than those with a wire deposition at $\pm 60^{\circ}$. The differences between the fracture strength values for the same sample filling rate but with a different orientation of \pm $45^{\circ}$ and $\pm 60^{\circ}$ deposition were much higher for the filling percentages of the $60 \%$ and $80 \%$ specimens. Differences between fracture strength values for the same $100 \%$ fill rate of the specimen but with a different orientation of $\pm 45^{\circ}$ and \pm $60^{\circ}$ deposition are insignificant. 


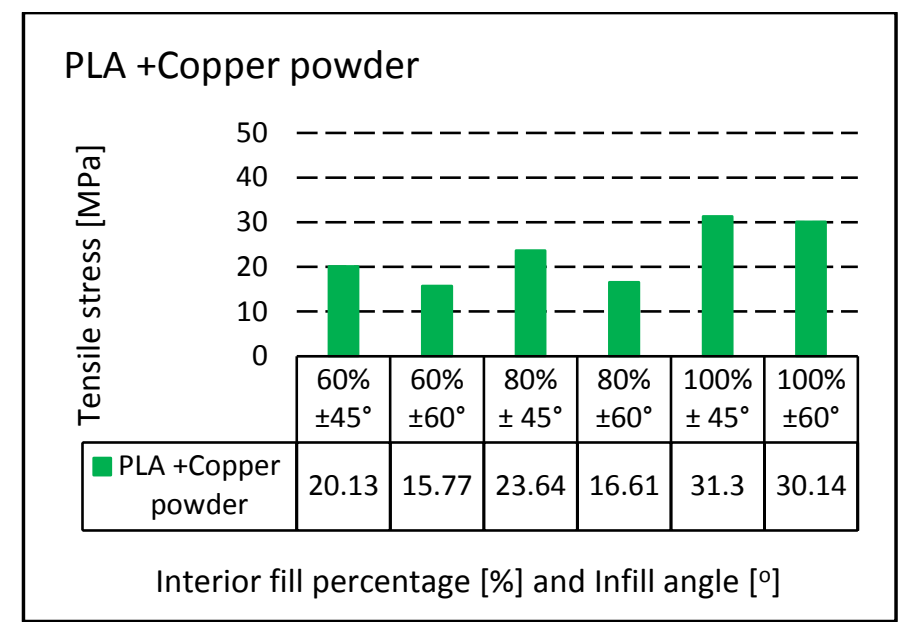

Fig. 6. Values of fracture strength for PLA with Copper powder specimens

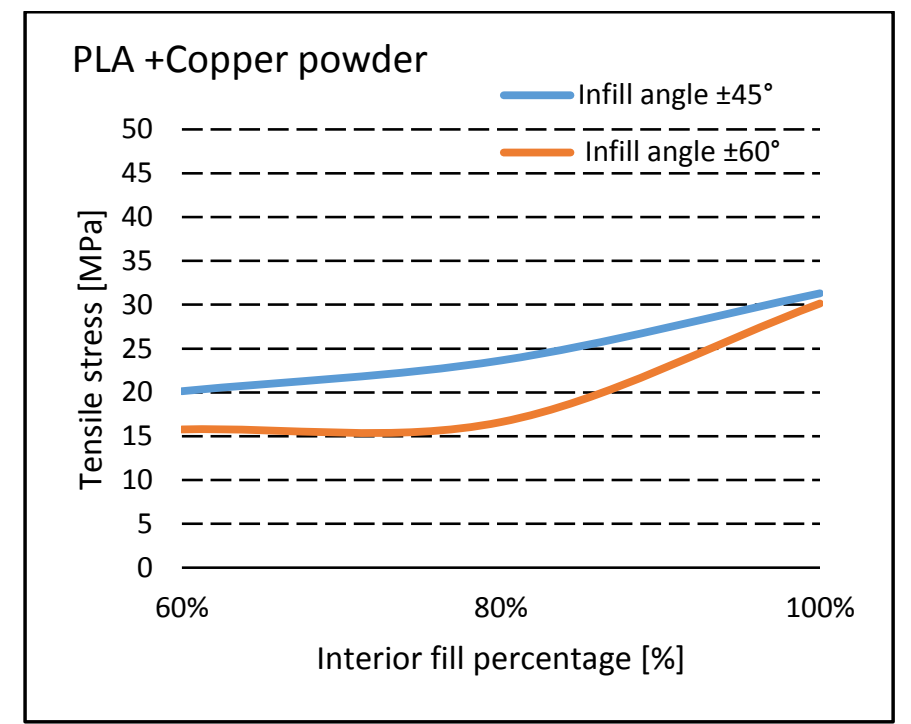

Fig. 7. Variation of fracture strength versus the filling percentage for PLA with Copper powder specimens

In case of PLA specimens with copper powder insertion (Figure 7) for thread deposition at $\pm 45^{\circ}$ compared to the deposition at $\pm 60^{\circ}$ the fracture strength is higher for all breakage rates. For PLA specimens with Copper powder insertion with thread deposition at $\pm 60^{\circ}$ on the graphic depicted in Figure 7, a decrease in tensile strength in the vicinity of $80 \%$ filling percentage of the specimen can be observed. These values are the lowest averages of the obtained ones within that series of tests.The tensile strength for the test specimens \# 37 $\div 54$ performed on the PLA specimens with aluminum powder insert (Figure 8) shows a small variation compared to those presented above from 19.65 [MPa] to 30.95 [MPa]. As can be seen in Figure 8, specimens for all filling types with thread deposition at $\pm 45^{\circ}$ are more resistant in tension than specimens with thread deposition at $\pm 60^{\circ}$. As in previous cases, the differences between the fracture strength values for the same percentage of the specimen filling but with a different orientation of $\pm 45^{\circ}$ and $\pm 60^{\circ}$ deposition were much higher for the fill percentages of the $60 \%$ and $80 \%$ specimens. The differences between the fracture strength values for the same percent filling, i.e. $100 \%$ of the specimen, but with a different orientation of $\pm 45^{\circ}$ and $\pm 60^{\circ}$ deposition, are insignificant.In Table 20 are synthesized data resulted during 3D printing process with PLA-Aluminum powder type of material. The specimens were ranking from 37 to 54 . 
Table 20

PLA WITH ALUMINUM POWDER

\begin{tabular}{|c|c|c|c|c|c|c|}
\hline Filling materials & \multicolumn{5}{|c|}{ Materials - Composite Metal: PLA + Aluminum } \\
\hline Interior fill percentage - $\%$ & \multicolumn{2}{|c|}{$60 \%$} & \multicolumn{2}{c|}{$80 \%$} & \multicolumn{3}{c|}{$100 \%$} \\
\hline Infill angle & $\pm 45^{\circ}$ & $\pm 60^{\circ}$ & $\pm 45^{\circ}$ & $\pm 60^{\circ}$ & $\pm 45^{\circ}$ & $\pm 60^{\circ}$ \\
\hline Number of samples tested & $37-39$ & $40-42$ & $43-45$ & $46-48$ & $49-51$ & $52-54$ \\
\hline $\begin{array}{c}\text { Build time provided by the softer } \\
\text { application [min] }\end{array}$ & 58 & 58 & 67 & 67 & 77 & 77 \\
\hline Real build time [min] & 60 & 61 & 69 & 70 & 80 & 80 \\
\hline Filament length [mm] & 3404.1 & 3402.9 & 4097.5 & 4098.2 & 4791.1 & 4782.1 \\
\hline Plastic weight [g] & 11.46 & 11.46 & 13.80 & 13.80 & 16.13 & 15.14 \\
\hline Filament density [g/cm ${ }^{3}$ ] & \multicolumn{7}{|c|}{1.4} & & & \\
\hline
\end{tabular}

In Tables 21-26 are depicted the obtained data of tests performed on PLA-Aluminum powder samples.

Table 21

PLA WITH ALUMINUM POWDER; INTERIOR FILL PERCENTAGE - 60\%; THREAD DEPOSITION AT $\pm 45^{\circ}$

\begin{tabular}{|c|c|c|c|}
\hline Specimen & $\begin{array}{c}\text { Force } \\
{[\mathrm{N}]}\end{array}$ & $\begin{array}{c}\text { Tensile stress } \\
{[\mathrm{MPa}]}\end{array}$ & $\begin{array}{c}\Delta \mathrm{L} \\
{[\mathrm{mm}]}\end{array}$ \\
\hline$\# 37$ & 950 & 18.96 & 3 \\
\hline$\# 38$ & 1000 & 19.97 & 3.5 \\
\hline$\# 39$ & 1000 & 20.01 & 3.2 \\
\hline
\end{tabular}

Table 22

PLA WITH ALUMINUM POWDER; INTERIOR FILL PERCENTAGE - 60\%; THREAD DEPOSITION AT $\pm 60^{\circ}$

\begin{tabular}{|c|c|c|c|}
\hline Specimen & $\begin{array}{c}\text { Force } \\
{[\mathrm{N}]}\end{array}$ & $\begin{array}{c}\text { Tensile stress } \\
{[\mathrm{MPa}]}\end{array}$ & $\begin{array}{c}\Delta \mathrm{L} \\
{[\mathrm{mm}]}\end{array}$ \\
\hline$\# 40$ & 860 & 17.27 & 4 \\
\hline$\# 41$ & 780 & 15.61 & 3.8 \\
\hline$\# 42$ & 830 & 16.51 & 4.5 \\
\hline
\end{tabular}

Table 23

PLA WITH ALUMINUM POWDER; INTERIOR FILL PERCENTAGE - 80\%; THREAD DEPOSITION AT $\pm 45^{\circ}$

\begin{tabular}{|c|c|c|c|}
\hline Specimen & $\begin{array}{c}\text { Force } \\
{[\mathrm{N}]}\end{array}$ & $\begin{array}{c}\text { Tensile stress } \\
{[\mathrm{MPa}]}\end{array}$ & $\begin{array}{c}\Delta \mathrm{L} \\
{[\mathrm{mm}]}\end{array}$ \\
\hline$\# 43$ & 1250 & 24.94 & 2.08 \\
\hline$\# 44$ & 132 & 26.4 & 2.02 \\
\hline$\# 45$ & 138 & 27.67 & 2.19 \\
\hline
\end{tabular}

Table 24

PLA WITH ALUMINUM POWDER; INTERIOR FILL PERCENTAGE - 80\%; THREAD DEPOSITION AT $\pm 60^{\circ}$

\begin{tabular}{|c|c|c|c|}
\hline Specimen & $\begin{array}{c}\text { Force } \\
{[\mathrm{N}]}\end{array}$ & $\begin{array}{c}\text { Tensile stress } \\
{[\mathrm{MPa}]}\end{array}$ & $\begin{array}{c}\Delta \mathrm{L} \\
{[\mathrm{mm}]}\end{array}$ \\
\hline$\# 46$ & 1190 & 23.89 & 2.3 \\
\hline$\# 47$ & 1130 & 22.66 & 2.5 \\
\hline$\# 48$ & 1150 & 23.08 & 2.41 \\
\hline
\end{tabular}


Table 25

PLA WITH ALUMINUM POWDER; INTERIOR FILL PERCENTAGE - 100\%; THREAD DEPOSITION AT $\pm 45^{\circ}$

\begin{tabular}{|c|c|c|c|}
\hline Specimen & $\begin{array}{c}\text { Force } \\
{[\mathrm{N}]}\end{array}$ & $\begin{array}{c}\text { Tensile stress } \\
{[\mathrm{MPa}]}\end{array}$ & $\begin{array}{c}\Delta \mathrm{L} \\
{[\mathrm{mm}]}\end{array}$ \\
\hline$\# 49$ & 1650 & 33.09 & 1.52 \\
\hline$\# 50$ & 1560 & 31.3 & 1.61 \\
\hline$\# 51$ & 1550 & 31 & 1.8 \\
\hline
\end{tabular}

Table 26

PLA WITH ALUMINUM POWDER; INTERIOR FILL PERCENTAGE - 100\%; THREAD DEPOSITION AT $\pm 60^{\circ}$

\begin{tabular}{|c|c|c|c|}
\hline Specimen & $\begin{array}{c}\text { Force } \\
{[\mathrm{N}]}\end{array}$ & $\begin{array}{c}\text { Tensile stress } \\
{[\mathrm{MPa}]}\end{array}$ & $\begin{array}{c}\Delta \mathrm{L} \\
{[\mathrm{mm}]}\end{array}$ \\
\hline$\# 52$ & 1560 & 31.2 & 1.91 \\
\hline$\# 53$ & 1550 & 31.05 & 1.91 \\
\hline$\# 54$ & 1530 & 30.6 & 2.1 \\
\hline
\end{tabular}

PLA +Aluminum powder

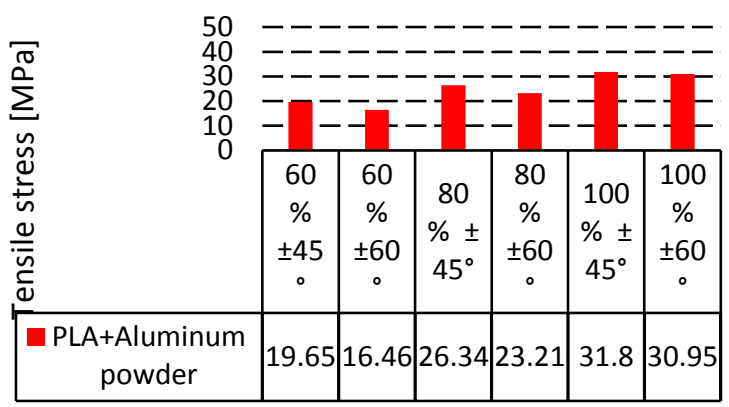

Interior fill percentage [\%] and Infill angle [0]

Fig. 8. Values of fracture strength for PLA with Aluminum powder specimens

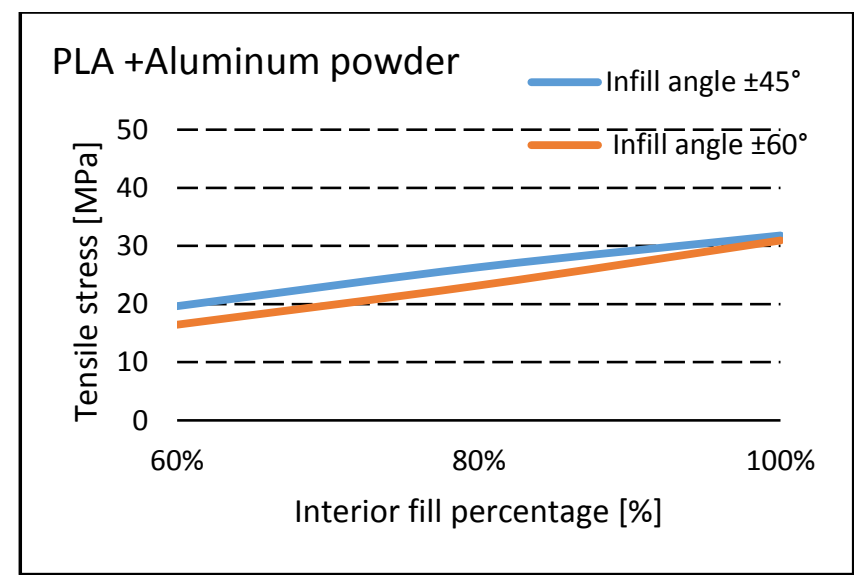

Fig. 9. Variation of fracture strength versus the filling percentage for PLA with Aluminum powder specimens 
In case of PLA specimens with Aluminum powder insertion (Fig. 9) for thread deposition at $\pm 45^{\circ}$ compared to the deposition at $\pm 60^{\circ}$ the fracture strength is higher for all breakage rates. For PLA specimens with an Aluminum powder insertion with thread deposition at $\pm 45^{\circ}$ and $\pm 60^{\circ}$, it can easily be seen from the graph represented in Figure 9, the curves of the fracture strength values for these specimens, according to the percentage of filling, have the same allure.

In Table 28 are synthesized data resulted during 3D printing process with PLA-Graphene powder insertions type of material. The specimens were ranking from 55 to 72 .

Table 27

PLA WITH GRAPHENE

\begin{tabular}{|c|c|c|c|c|c|c|}
\hline Filling materials & \multicolumn{7}{|c|}{ Materials - Composite: PLA + Graphene } \\
\hline Interior fill percentage - $\%$ & \multicolumn{2}{|c|}{$60 \%$} & \multicolumn{2}{c|}{$80 \%$} & \multicolumn{2}{c|}{$100 \%$} \\
\hline Infill angle & $\pm 45^{\circ}$ & $\pm 60^{\circ}$ & $\pm 45^{\circ}$ & $\pm 60^{\circ}$ & $\pm 45^{\circ}$ & $\pm 60^{\circ}$ \\
\hline Number of samples tested & $55-57$ & $58-60$ & $61-63$ & $64-66$ & $67-69$ & $70-72$ \\
\hline $\begin{array}{c}\text { Build time provided by the softer } \\
\text { application [minutes] }\end{array}$ & 46 & 46 & 54 & 54 & 61 & 61 \\
\hline Real build time [minutes] & 55 & 56 & 65 & 66 & 75 & 78 \\
\hline Filament length [mm] & 3404.2 & 3402.2 & 4103.7 & 4103.3 & 4805.1 & 4804.2 \\
\hline Plastic weight [g] & 10.23 & 10.23 & 12.34 & 12.34 & 14.45 & 14.44 \\
\hline Filament density [g/cm ${ }^{3}$ ] & \multicolumn{2}{|c|}{1.24} & & \\
\hline
\end{tabular}

In Tables 28-33 are depicted the obtained data of tests performed on PLA with Graphene samples.

Table 28

PLA WITH GRAPHENE; INTERIOR FILL PERCENTAGE - 60\%; THREAD DEPOSITION AT $\pm 45^{\circ}$

\begin{tabular}{|c|c|c|c|}
\hline Specimen & $\begin{array}{c}\text { Force } \\
{[\mathrm{N}]}\end{array}$ & $\begin{array}{c}\text { Tensile stress } \\
{[\mathrm{MPa}]}\end{array}$ & $\begin{array}{c}\Delta \mathrm{L} \\
{[\mathrm{mm}]}\end{array}$ \\
\hline$\# 55$ & 930 & 18.67 & 3.25 \\
\hline$\# 56$ & 1070 & 21.41 & 3.3 \\
\hline$\# 57$ & 1020 & 20.32 & 3.45 \\
\hline
\end{tabular}

Table 29

PLA WITH GRAPHENE; INTERIOR FILL PERCENTAGE - 60\%; THREAD DEPOSITION AT $\pm 60^{\circ}$

\begin{tabular}{|c|c|c|c|}
\hline Specimen & $\begin{array}{c}\text { Force } \\
{[\mathrm{N}]}\end{array}$ & $\begin{array}{c}\text { Tensile stress } \\
{[\mathrm{MPa}]}\end{array}$ & $\begin{array}{c}\Delta \mathrm{L} \\
{[\mathrm{mm}]}\end{array}$ \\
\hline$\# 58$ & 660 & 13.19 & 4 \\
\hline$\# 59$ & 810 & 16.24 & 4.25 \\
\hline$\# 60$ & 840 & 16.86 & 3.75 \\
\hline
\end{tabular}

Table 30

PLA WITH GRAPHENE; INTERIOR FILL PERCENTAGE - 80\%; THREAD DEPOSITION AT $\pm 45^{\circ}$

\begin{tabular}{|c|c|c|c|}
\hline Specimen & $\begin{array}{c}\text { Force } \\
{[\mathrm{N}]}\end{array}$ & $\begin{array}{c}\text { Tensile stress } \\
{[\mathrm{MPa}]}\end{array}$ & $\begin{array}{c}\Delta \mathrm{L} \\
{[\mathrm{mm}]}\end{array}$ \\
\hline$\# 61$ & 1370 & 27.32 & 2.5 \\
\hline$\# 62$ & 1340 & 26.77 & 2.75 \\
\hline$\# 63$ & 1330 & 26.68 & 2.8 \\
\hline
\end{tabular}


Table 31

PLA WITH GRAPHENE; INTERIOR FILL PERCENTAGE - 80\%;

THREAD DEPOSITION AT $\pm 60^{\circ}$

\begin{tabular}{|c|c|c|c|}
\hline Specimen & $\begin{array}{c}\text { Force } \\
{[\mathrm{N}]}\end{array}$ & $\begin{array}{c}\text { Tensile stress } \\
{[\mathrm{MPa}]}\end{array}$ & $\begin{array}{c}\Delta \mathrm{L} \\
{[\mathrm{mm}]}\end{array}$ \\
\hline$\# 64$ & 1160 & 23.21 & 2.65 \\
\hline$\# 65$ & 1460 & 29.14 & 2.65 \\
\hline$\# 66$ & 1350 & 26.93 & 2.7 \\
\hline
\end{tabular}

Table 32

PLA WITH GRAPHENE; INTERIOR FILL PERCENTAGE - 100\%; THREAD DEPOSITION AT $\pm 45^{\circ}$

\begin{tabular}{|c|c|c|c|}
\hline Specimen & $\begin{array}{c}\text { Force } \\
{[\mathrm{N}]}\end{array}$ & $\begin{array}{c}\text { Tensile stress } \\
{[\mathrm{MPa}]}\end{array}$ & $\begin{array}{c}\Delta \mathrm{L} \\
{[\mathrm{mm}]}\end{array}$ \\
\hline$\# 67$ & 1750 & 34.92 & 2.35 \\
\hline$\# 68$ & 2020 & 40.37 & 2.4 \\
\hline$\# 69$ & 1990 & 39.87 & 3.2 \\
\hline
\end{tabular}

Table 33

PLA WITH GRAPHENE; INTERIOR FILL PERCENTAGE - 100\%; THREAD DEPOSITION AT $\pm 60^{\circ}$

\begin{tabular}{|c|c|c|c|}
\hline Specimen & $\begin{array}{c}\text { Force } \\
{[\mathrm{N}]}\end{array}$ & $\begin{array}{c}\text { Tensile stress } \\
{[\mathrm{MPa}]}\end{array}$ & $\begin{array}{c}\Delta \mathrm{L} \\
{[\mathrm{mm}]}\end{array}$ \\
\hline$\# 70$ & 1960 & 39.15 & 2.4 \\
\hline$\# 71$ & 1980 & 39.5 & 2.5 \\
\hline$\# 72$ & 1980 & 39.51 & 2.6 \\
\hline
\end{tabular}

Tensile strength for the test specimens \# $55 \div 72$ performed on Graphene powder insertions (Figure 10) shows a significant variation from 20.13 [MPa] to 39.39 [MPa]. As it can be seen in Figure 10, the specimens with $60 \%$ respectively $80 \%$ infill with a thread deposition at $\pm 45^{\circ}$ are more resistant in tension than those with a wire deposition at $\pm 60^{\circ}$. The differences between the fracture strength values for the same sample fill rate but with a different orientation of $\pm 45^{\circ}$ and $\pm 60^{\circ}$ deposition were much higher for the fill percentages of the $60 \%$ and $80 \%$ specimens. In the same time, from the same graph shown in Figure 10 it can be seen that for this combination of test material for $100 \%$ the fracture strength is higher for a deposition at $\pm 60^{\circ}$ than deposition to $\pm 45^{\circ}$, differences in fracture strength being insignificant

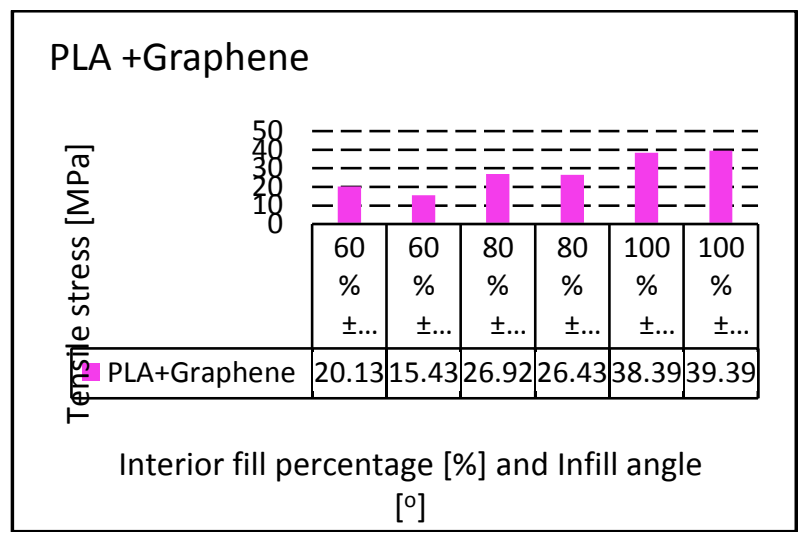

Fig. 10. Values of fracture strength for PLA with Graphene specimens 


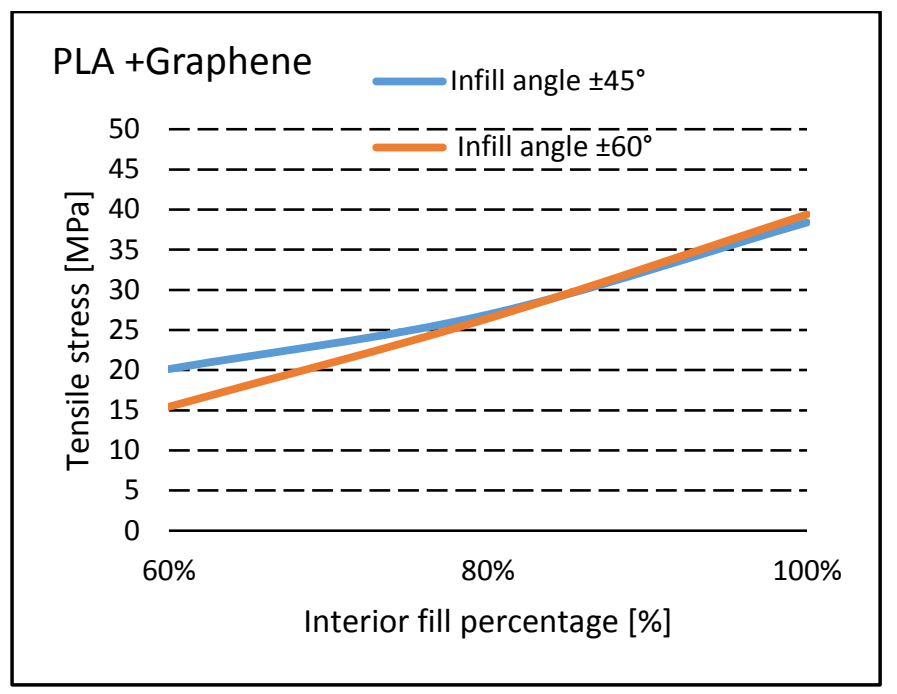

Fig. 11. Variation of fracture strength versus the filling percentage for PLA with Graphene specimens

In the case of PLA + Graphene specimens (Fig. 11) for thread deposition at $\pm 45^{\circ}$ compared to the deposition at $\pm 60^{\circ}$ the fracture strength is higher only for the percentages close to the $60 \%$ filling degree. As the specimens' filling percentage increases, the thread deposition at $\pm 45^{\circ}$ and $\pm 60^{\circ}$ can easily be seen from the graph depicted in Figure 11, the curves of the fracture strength values for these specimens, depending on the percentage of filling, overlap.

An important component of the experimental test attempts is the filling percentage of the specimens. In Figures 12, 13 and 14 are shown variations of the fracture strength according to the type of material for the two directions of deposition of the wires $\pm 45^{\circ}$ and $\pm 60^{\circ}$ respectively.

From the chart shown in Figure 12 (in the case of interior fill percentage - 60\%), it can be noticed that the PLA + Copper powder filaments have a close fracture strength as average values with those of PLA + Graphene specimens and very close to the average values of PLA + Aluminum powder specimens. PLA specimens do not align with these values. The graph also shows that for this filling percentage of the specimen, the samples obtained by thread deposition at $\pm 45^{\circ}$ have a higher breaking strength than the ones obtained by depositing the thread at $\pm 60^{\circ}$ in case of powder-coated specimens. For PLA specimens, the samples obtained by thread deposition at $\pm 60^{\circ}$ have a fracture strength higher than the specimens obtained by a thread deposition at $\pm 45^{\circ}$.

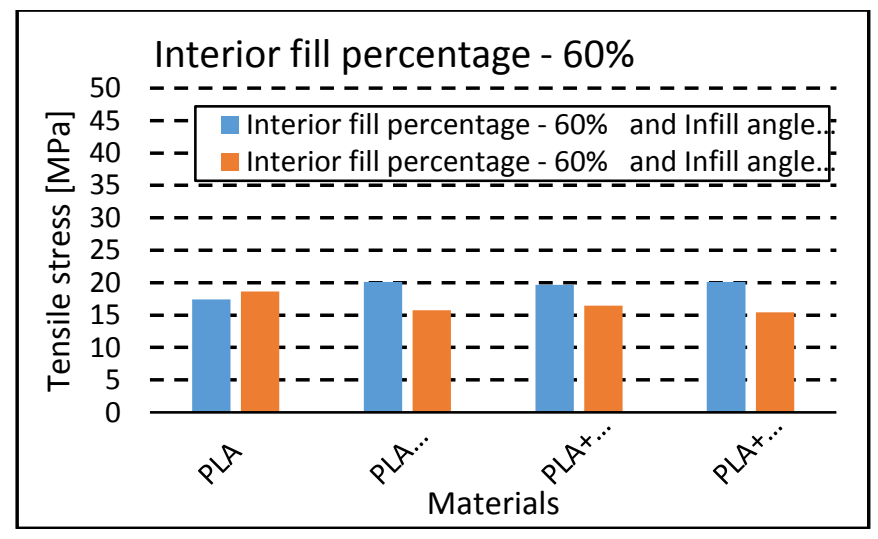

Fig. 12. Variations of fracture strength for each specimen filling percentage of $60 \%$ 
From the chart depicted in Figure 13 (in the case of Interior fill percentage - 80\%) it can be seen that the PLA + Copper powder filaments have a low fracture strength compared to the others. The graph also shows that for this filling percentage of the specimen, the samples obtained by depositing the thread at $\pm 45^{\circ}$ have a higher fracture strength than the samples obtained by depositing the thread at $\pm 60^{\circ}$ for all specimens. Also from the same graph we can rank the materials according to fracture strength as follows: PLA specimens have the highest tensile strength, the PLA + Graphene and PLA + Aluminum powder specimens are close and follow the PLA and PLA + Copper powder samples have the lowest breaking strength.

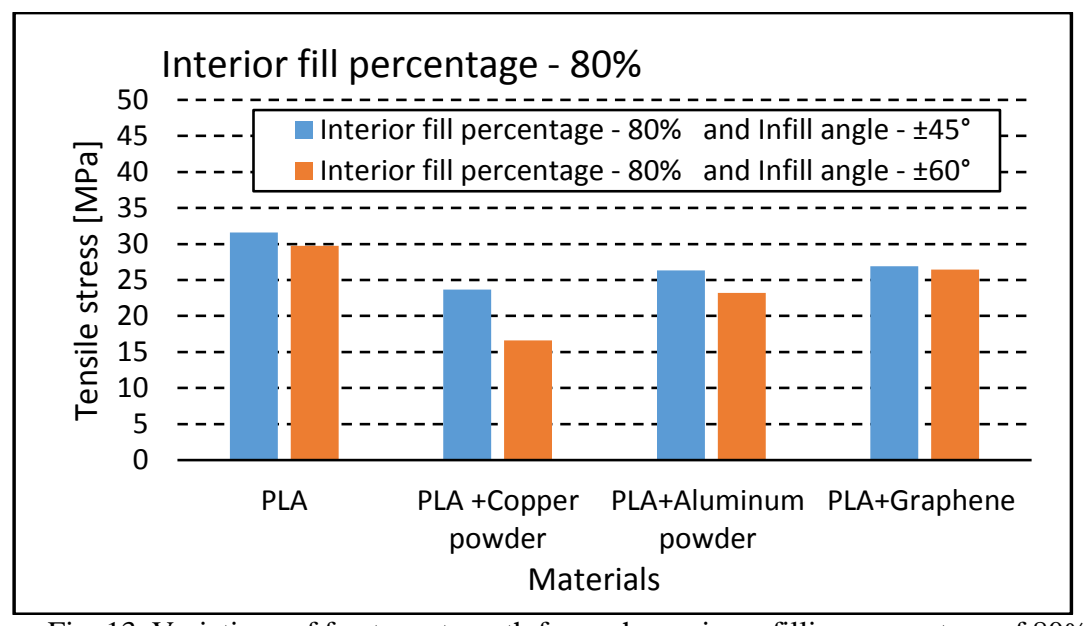

Fig. 13. Variations of fracture strength for each specimen filling percentage of $80 \%$

From the graph depicted in Figure 14 (in case of internal filling percentage of 100\%) it can be seen that the PLA + Copper powder filaments have a close fracture strength regarding the average values to those with PLA + Aluminum powder.

PLA specimens do not align with these values, these ones presenting the highest fracture strength for both types of thread deposition.

The graph shows also that for this filling percentage of the specimen, the samples obtained by thread deposition at \pm $60^{\circ}$ have a higher fracture strength than those obtained by depositing the thread at $\pm 45^{\circ}$ in case of PLA and PLA + Graphene specimens.

For PLA + Copper and PLA + Aluminum metal powder specimens, the samples obtained by thread deposition at \pm $60^{\circ}$ have a fracture strength close to that of the specimens obtained by thread deposition at $\pm 45^{\circ}$ and for both materials the deposition at $\pm 45^{\circ}$ is more advantageous in terms of tensile strength.

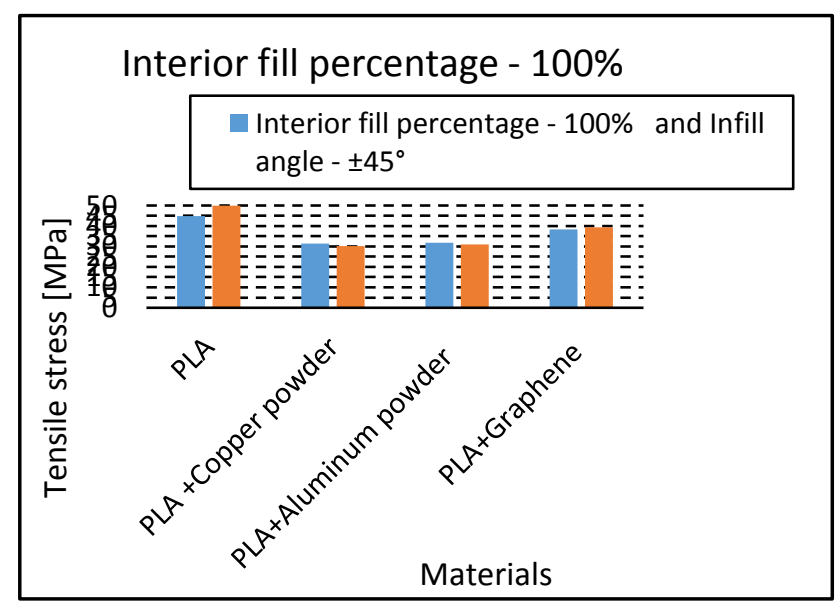

Fig. 14. Variations of the fracture strength for each specimen, infill percentage - $100 \%$ 
During the printing process some difficulties arose regarding the adhesion of the materials to the printing platform. Thus, the version directly printed on the platform glass through an adhesive was not adopted because for this printer type (with a $300 \times 300[\mathrm{~mm}]$ high print bed) the specimens did not adhere to the printing plate, their construction being sometimes deformed and during the printing process, the test specimens were unevenly contracted in the clamping area on the folding bed. Finally, it was adopted the specimens' fixation using the Kapton tape which was changed to each print in order to ensure the same printing conditions for the test specimen. Also from an initial test phase in the data collected from the slicing program of the geometric models Tables 5, 13, 20 and 27 it can be noticed that there is a difference between the test time of the samples provided by the slicing software and the actual time of making the specimens.

\section{Conclusions}

The data from the tests showed variations between the different sets of specimens for both PLA and PLA with powder insertions. There were no sets showing large internal differences. In Tables $6 \div 11,14 \div 19,21 \div 26$ and $28 \div 33$ the authors presented such sets of values obtained during the tests. Concluding we can say that: PLA specimens have the best UTS (Ultimate Tensile Strength). The best UTS values correspond to specimen \# 21 with a $100 \%$ fill density at an extrusion temperature of $205\left[{ }^{\circ} \mathrm{C}\right]$ with a raster angle of $\pm 60\left[{ }^{\circ} \mathrm{C}\right]$ and a layer thickness of $0.1[\mathrm{~mm}]$. The higher filling percentage of the specimen, the higher UTS.The PLA with Aluminum powder specimens are more brittle than the other ones, suffering small deformations before breaking. The UTS for specimens with $\pm 45^{\circ}$ angle of deposition has a linear variation whereas, in case of specimens with $\pm 60^{\circ}$ angle of deposition this variation is exponential, with maximum values for $100 \%$ PLA. However, it is clear from the previous results that components printed on cheap 3D printers, with low-cost filaments can be considered mechanically functional in tensile applications as well as those of large commercial vendors. However, for PLA-containing material in the PLA matrix, although the tensile strength is comparable to PLA's for certain filling densities, their fragility limits their use in applications where plastic deformation is required at higher stress levels.

\section{References}

1. MESSIMER, L.S. et al., Characterization and Processing Behavior of Heated Aluminum-Polycarbonate Composite Build Plates for the FDM Additive Manufacturing Process. Journal of Manufacturing and Materials Processing, 8, 2, 2018, p. 12.

2. $\quad$ AURAS, R., B. HARTE, B., SELKE, S., An Overview of Polylactides as Packaging Materials.Macromol. Biosci., 4, 2004, p. 835.

3. NARAYANAN, N., ROYCHOUDHURY, P.K., SRIVASTAVA, A., L (+) lactic acid fermentation and its product polymerization. Electronic Journal of Biotechnology, 7, 2004, p. 167.

4. VINK, E.T.H., RÁBAGO, K.R., GLASSNER, D.A., SPRINGS, B., O'CONNOR, R.P., KOLSTAD, J., GRUBER, P.R., The sustainability of Nature Works Polylactide polymers and Ingeopolylactide fibers: an update of the future. Macromol. Biosci., 4, 2004, p. 551.

5. JAMSHIDI, K., HYON, S.-K, IKADA, Y., Thermal characterization of polylactides, Polymer, 29, 1998, p. $2229-2234$.

6. Creative Mechanisms. Available at: www.creativemechanisms.com.

7. MARTIN, O., AVÉROUS L., Poly (lactic acid): plasticization and properties of biodegradable multiphase systems. Polymer, 42, 2001, p. 6209-6219.

8. $\quad$ DRUMRIGHT, R.E., GRUBER, P.R., HENTON, D.E., Polylactic acid technology. Adv. Mater, 12, 2000, p. 1841-1846.

9. SAVIOLI LOPES, M., JARDINI, A.L., MACIEL-FILHO, R., Poly (Lactic Acid) Production for Tissue Engineering Applications.Procedia Eng., 42, 2012, p. 1402-1413.

10. LASPRILlA, A.J., MARTINEZ, G.A., LUNELli, B.H., JARDINI, A.L., FILHO, R.M. Poly-lactic acid synthesis for application in biomedical devices - a review. Biotechnol. Adv., 30, 2012, p. 321-328

11. MALMGREN, T., MAYS, J., PYDA, M., Characterization of polylactic acid by size exclusion chromatography, differential refractometry, light scattering and thermal analysis. Therm. Anal. Calorim., 83, 20006, p. 35-40.

12. VALERGA, A. et al., Influence of PLA filament condition on characteristics of FDM parts, Materials, 1322, 11, 2018 , p. 8.

13. Creality. Available at: https://www.creality3d.cn.

14. Autodesk. Available at: https://www.autodesk.eu.

15. Simplify. Available at: https://www.simplify3d.com/version-3-1-and-printer-compatibility-tool.

16. INSTRON. Available at: http://www.instron.com.

17. FILOALFA. Available at: www.filoalfa3d.com.

18. VASILESCU, M.D., FLESER, T., Influence of Technological Parametrs on the Dimension of Threaded Parts Generated with PLA Matherial by FDM 3D Printing, Mat. Plast., 55, no. 4, 2018, p. 718-722.

19. PENG, F., ZHAO, Z., XIA, X., et al., Enhanced Impact Resistance of Three-Dimensional-Printed Parts with Structured Filaments, ACS Applied Mat.\& Interfaces, 10(18), 2018, p. 16087-16094. 
20. BESNEA, D., DINU, E., MORARU, E., et al., Experimental Researches Regarding the Manufacturing of New Thermoplastic Materials Used in Additive Technologie, Mat. Plast., 56, no. 1, 2019, p. 167-170.

21. VASILESCU, M.D., Constructiv and Technological Consideration on the Generation of Gear Made by the DLP 3D-Printed Methode, Mat. Plast., 56 , no. 2, 2019, p. 440-444.

22. DRĂGHICI, S., PETRESCU, H.A., HADĂR, A., On obtaining the Young modulus from numerical analysis of composite material constituent, Mat. Plast. 55, no. 4, p .712-717.

Manuscript received: 22.10 .2019 